\title{
Jaettuja muistoja tyttöenergiasta
}

Tormulainen, Aino (2018). Tyttöenergialla kasvaneet. Postfeministisen populaarikulttuuri-ilmiön yhdessä muistellut merkitykset. Nuorisotutkimusverkosto. 308 sivua.

Nimensä MUKaIsesti Tyttöenergialla kasvaneet kuvaa tyttöenergiaa 1990-luvun teinien muisteluiden pohjalta. Muisteluihin virittäneet aikalaisaineistot ovat Musiikkiarkiston ja Suomalaisen Kirjallisuuden Seuran arkistokokoelmista.

\section{AIKALAISAINEISTO TÄYDENTÄÄ MUISTELUAINEISTOA}

Keskeiseksi muisteluiden teemaksi nousee Spice Girls -yhtyeestä virinnyt tyttöenergiailmiö. Kulttuuritutkimuksen alan väitöskirjassaan Aino Tormulainen määrittelee tyttöenergian postfeministiseksi ja populaarikulttuuriseksi sukupolvikokemukseksi. Hän kuvaa ilmiön moninaisuutta kattavasti ja pohtii girl power - ja tyttöenergia-käsitteiden luonnetta ja merkitysulottuvuuksia monipuolisesti.

Aikalaisaineistot täydentävät muisteluaineistoa ja kuvaavat 1990-luvun tyttöenergiakulttuuria. Ne taustoittavat muisteluaineistoa ja antavat lukijalle ymmärryksen aikakauden tyttöenergiakulttuurista.

Kirjoittaja kuvaa teinien monisäikeisiä kokemuksia aikaan ja paikkaan sekä yhteisöllisyyteen, sosiaalisiin suhteisiin ja sukupolvikokemuksiin liittyen. Hän tarkastelee sukupuolta ja sukupuolittamista niin aikalaisaineistojen kuin osallistujien muistojen kautta.

Sukupuoli on tarkastelun kohteena myös ruumiillisuutta ja seksuaalisuutta koskevissa muistoissa erityisesti "Tyttöenergiamuistojen tulkinta aikuisen silmin" -luvussa. Muistot kerrotaan nykyisyyden kautta, sillä aikuisena ruumiillisuuden ja seksuaalisuuden ymmärtäminen ovat paremmin tulkittavissa kuin nuorena. Tormulainen analysoi hienosti sitä, kuinka mennyt muuttuu nostalgiseksi, nykyisyyttä paheksutaan liian seksuaalisoivana, ja moraalinen aikuisen ääni kuuluu puheessa.

\section{MUISTELU ON YHTEISKUNNAN ILMIÖIDEN REFLEKTOINTIA}

Yhdessä muistelu tuottaa jaettua kokemusta muistelun kohteena olevista ilmiöistä. Se ei jää pelkästään kokemusten kertomiseksi, vaan parhaimmillaan se on yhteiskunnan rakenteiden ja yksilöiden arjen käytäntöjen analysointia. Tormulaisen käyttämä muistelutyömenetelmä pohjautuu tutkija Frigga Haugin (1987) ja hänen tutkijaryhmänsä kehittämään menetelmään. Se puolestaan perustuu omien muistojen kertomiseen ryhmässä ja niiden tarkasteluun yksilöllisestä ja yhteiskunnallisesta näkökulmasta. Näin tehdään erilaisia toimintatapoja näkyviksi ja pohditaan arjen sukupuolittuneita

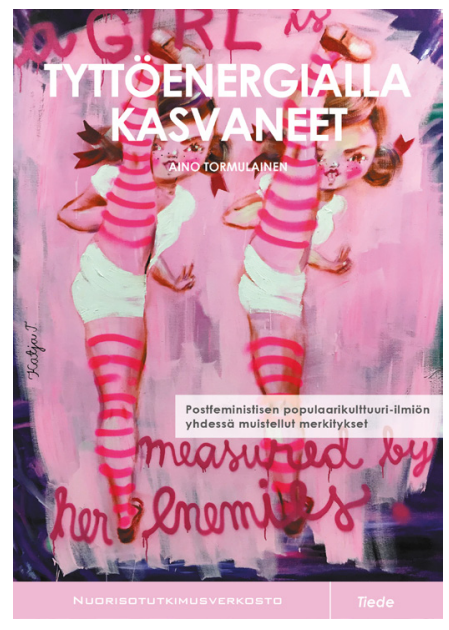

ilmiöitä. Keskeinen ajatus on kokemusten jakaminen ryhmässä, jolloin tieto muodostuu niin subjektiivisesti kuin kollektiivisesti.

Tormulaisen tutkimuksen muisteluaineisto luo hienon aikamatkan 1990-2000-lukujen tyttöenergian populaarikulttuuriin. Teos kuvaa kattavasti muistojen tutkimusta koskevia käsitteitä, kuten muistoja, kokemusta ja muistelukerrontaa, sekä menetelmällisiä ratkaisuja tutkimusprosessin aikana.

Kirjoittaja avaa tutkimusprosessin ja ryhmätapaamisten aikana kohtaamiaan haasteita ja ryhmien erilaisuutta. Muisteluihin liittyvien keskusteluiden syvyys vaihteli ryhmittäin. Yhdessä ryhmässä muistelijat olivat hyvin avoimia, toisessa muistelijat taas pitäytyivät kulttuurisesti sovinnaisten muistojen kerronnassa.

\section{TUTKIJA RAKENTAA} LUOTTAMUKSEN ILMAPIIRIÄ

Kun ryhmäläiset tuntevat olonsa turvallisiksi, syntyy luottamuksen 
ilmapiiri, jossa voi jakaa omia kokemuksia. Tutkija luo ryhmän ilmapiiriä, osallistujat ryhmäidentiteettiä. Muistelutyömenetelmässä tutkija on aktiivinen ja osallistuva.

Kyetäkseen osallistumaan aktiivisesti ryhmän muisteluun tutkijan on pohdittava omaa paikkaansa, mikä näkyy teoksessa varsin tarkkoina pohdintoina. Tormulainen pohtii omaa positiotaan osallistujana, keskustelunohjaajana sekä vertaisena ja reflektoi näitä rooleja ansiokkaasti. Omien muistojen jakaminen tiivistää ryhmää, ja kertominen tuottaa yhteenkuuluvuutta. Tutkijan rooli vertaisena on välttämätön yhteyden tunteen syntymiselle.

Muistelut herättävät monenlaisia tunteita: iloa, surua, katkeruutta ja hauskuutta. Silloin erityisesti muistelutyöskentelyn terapeuttinen ulottuvuus todentuu. Muistelu ei kuitenkaan ole terapiaa vaan elämän ilmiöiden pohtimista niin yksilö- kuin yhteisötasolla. Tormulaisesta huomion arvoista on se, mitä ja mistä kerrotaan ja mistä vaietaan. Tutkimusprosessin aikana häneltä kysyttiin useaan kertaan, ketkä jäävät tyttöenergian ulkopuolelle.

\section{TOISENLAINEN KUVA TYTTÖKULTTUURISTA}

Rinnakkain Tormulaisen teoksen kanssa luin kirjailija, toimittaja Koko Hubaran esseekokoelmaa Ruskeat Tytöt (2015), joka kuvaa samaa aikakautta. Hubaran kokemukset luovat toisenlaisen suomalaisen teinin kulttuurikuvan, joka ei tullut tyttöenergiaa tutkittaessa esiin. Teosten lähtökohdat ovat erilaiset, mutta kumpikin muistuttaa siitä, kuinka erilaista elämää elämme samassa maassa, samassa kulttuurissa ja kuinka meidän kaikkien tulee olla avarakatseisia.

Tormulaisen kuvaama sukupolvikokemus ei kosketa kaikkia 1990-luvun tyttöjä eikä Spice Girls -ilmiö tarttunut kaikkiin tyttöihin. Kirjoittaja toivoo, että teos auttaa lukijoita pohtimaan omia kokemuksiaan nuoruudesta ja elämästä yleensä. Väistämättä toive toteutuu, sillä lukijana palasin moniin nuoruuteni fanituksiin ja kapinointiin aikuisten jähmettyneitä ajatuksia kohtaan. Samastuin tutkimuksen tyttöihin, vaikka vietinkin oman nuoruuteni vuosikymmentä aiemmin.

\section{TEOS KUULUU JOKAISELLE KASVATTAJALLE}

Monografinen väitöstutkimus on ehyt kertomus tyttöenergialla kasvaneista. Se avaa vakuuttavasti nuorten tyttöjen 1990-luvun aikakautta monin sävyin ja tapahtumin. Lukijalle piirtyy näkökulmia siihen, miten nuorten populaarikulttuuri rakentuu nuortenkirjallisuuden, lehtien, elokuvien, musiikin, tv-ohjelmien ja vertaisryhmien tuottamina.

Teos myös kuvaa nuorten maailmaa ennen internetiä ja somea. Silloin kirjastot olivat kohtaamispaikkoja, joissa luettiin, lainattiin nuorisolehtiä ja kuunneltiin musiikkia. Nyt niissä näkee enemmän entisiä nuoria lukemassa lehtiä.

Aikuiskasvatuksen tutkijoita ja lukijoita kiehtoo teoksen anti muistelutyöskentelystä tutkimusmenetelmänä. Sitä voi soveltaa myös aikuisten opetuksessa ja ohjaustilanteissa (Kutuniva \& Ylitapio-Mäntylä 2005; Mäkiranta \& Ylitapio-Mäntylä 2013). Sukupuolentutkimuksesta kiinnostuneet tutkijat saavat monipuolisen kuvan tyttöenergiaa ja feminististä tutkimusta koskevista teoreettisista ja metodologisista näkökulmista.

Toivon teoksen päätyvän lisäksi kaikkien kasvattajien, kuten opettajien ja ohjaajien, sekä kasvatustieteiden opiskelijoiden käsiin. Se avaa oivallisen näkökulman nuorten elämään tyttöjen näkökulmasta, menneeseen maailmaan ja nuoruuteen laajemminkin.

OUTI YLITAPIO-MÄNTYLÄ

$K T$, dosentti, yliopistonlehtori

Oulun yliopisto

\section{LÄHTEET}

Haug, F. (1987). Female

Sexualization. The Collective Work of Memory. London: Verso.

Hubara, K. (2015). Ruskeat Tytöt.

Helsinki: Like.

Kutuniva, M. \& Ylitapio-Mäntylä, O. (2005). Matkalla itseen ja yhteiseen - muistoista yhdessä oppimiseen. Teoksessa Mietola, R., Lahelma, E. Lappalainen, S. \& Palmu, T. (toim.) Kohtaamisia kasvatuksen ja koulutuksen kentillä: erontekoja ja yhdessä tekemistä. Turku: Suomen kasvatustieteen seura. Kasvatusalan tutkimuksia 22, 239-256.

Mäkiranta, M. \& Ylitapio-Mäntylä, O. (2013). Care and emotional looking in memory-based photographs. Teoksessa KeskitaloFoley, S., Naskali, P. \& Rantala, P. (eds.) Northern Insights: Feminist Inquiries into Politics of Place, Knowledge and Agency. Rovaniemi: Lapin yliopistokustannus, 56-74. 